\title{
Role of adventitious roots in water relations of tamarack (Larix laricina) seedlings exposed to flooding
}

\author{
Mónica Calvo-Polanco, Jorge Señorans and Janusz J Zwiazek*
}

\begin{abstract}
Background: Flooding reduces supply of oxygen to the roots affecting plant water uptake. Some flooding-tolerant tree species including tamarack (Larix laricina (Du Roi) K. Koch) produce adventitious roots in response to flooding. These roots were reported to have higher hydraulic conductivity under flooding conditions compared with non-adventitious roots. In the present study, we examined structural and functional modifications in adventitious roots of tamarack seedlings to explain their flooding tolerance.

Results: Seedlings were subjected to the flooding treatment for six months, which resulted in an almost complete disintegration of the existing root system and its replacement with adventitious roots. We compared gas exchange parameters and water relations of flooded plants with the plants growing in well-drained soil and examined the root structures and root water transport properties. Although flooded seedlings had lower needle chlorophyll concentrations, their stomatal conductance, net photosynthesis rates and shoot water potentials were similar to non-flooded plants, indicative of flooding tolerance. Flooded adventitious roots had higher activation energy and a higher ratio of apoplastic to cell-to-cell water flow compared with non-flooded control roots as determined with the 1-hydroxypirene 3,6,8-trisulfonic acid apoplastic tracer dye. The adventitious roots in flooded plants also exhibited retarded xylem and endodermal development and accumulated numerous starch grains in the cortex. Microscopic examination of root sections treated with the PIP1 and PIP2 antibodies revealed high immunoreactivity in the cortex of non-flooded roots, as compared with flooded roots.

Conclusions: Structural modifications of adventitious roots suggest increased contribution of apoplastic bypass to water flow. The reduced dependence of roots on the hypoxia-sensitive aquaporin-mediated water transport is likely among the main mechanisms allowing tamarack seedlings to maintain water balance and gas exchange under flooding conditions.
\end{abstract}

\section{Background}

Flooding creates hypoxic conditions around the roots affecting a number of physiological processes in plants including gas exchange, carbohydrate metabolism and water relations [1-3]. Some woody plants that are adapted to flooding conditions develop hypertrophic lenticels and/or root aerenchyma to increase aeration $[4,5]$. In other species, including tamarack (Larix laricina ( $\mathrm{Du}$ Roi) K. Koch), flooding triggers the development of adventitious roots, which help the trees tolerate seasonal

\footnotetext{
* Correspondence: jzwiazek@ualberta.ca

Department of Renewable Resources, University of Alberta, 442 Earth Sciences Bldg, Edmonton AB T6G 2E3, Canada
}

changes in water levels [6]. However, the mechanisms through which adventitious roots contribute to flooding tolerance of the tree and those that enable the roots to survive hypoxic conditions remain unclear. Adventitious roots in tamarack are often present below the water level for extended periods of time $[7,8]$ and, therefore, they must be adapted to low oxygen conditions.

Stomatal closure and wilting are among the initial symptoms of oxygen deficiency in the root zone [1,9] due to the reduced ability of the root system to conduct water [10-12]. The maintenance of fine balance between the water loss and water uptake requires adjustments in tissue hydraulic conductivity. Most of the dynamic regulation of root hydraulic conductivity has been attributed 
to the transmembrane water flow regulated by the aquaporins. The reduction of root hydraulic conductivity in hypoxic plants has been linked to the inhibition of aquaporin-mediated water transport through root metabolic changes [12,13] and low cytoplasmic $\mathrm{pH}[14]$, and could be partly alleviated by the treatment of plants with ethylene $[11,15]$. In flooded tamarack seedlings, the emergence of adventitious roots coincided with an increase in hydraulic conductance of the root system [16]. Adventitious roots in tamarack were also reported to have higher hydraulic conductivity (conductance expressed on the root volume basis) under flooding conditions compared with non-adventitious roots of the same tree [16] suggesting that adventitious roots may posses functional modifications which make them less sensitive to flooding.

Since aquaporins are sensitive to hypoxia [12,13], the adaptations of adventitious roots to flooding likely include modifications that are aimed at making the roots less dependent on the transmembrane water transport. An increase in apoplastic water pathway could reduce the dependence of root water transport on aquaporins, but it could also compromise the benefits of selective permeability of the transmembrane pathway. In the present study, we examined the hypothesis that the adventitious roots produced in tamarack in response to flooding are able to maintain high hydraulic conductivity by developing structural and functional modifications that increase the apoplastic bypass. In turn, these features enable flooded plants to maintain stomatal conductance and photosynthesis to sustain carbohydrate supply to the roots. We subjected seedlings to six months of flooding, which resulted in the replacement of the existing root system with newly-produced adventitious roots. We then compared the gas exchange and water relations of flooded plants with the plants growing in a well-drained soil and examined the differences in root structure and relative contributions of apoplastic and cell-to-cell pathways in flooded and non-flooded plants.

\section{Results}

Dry weights, gas exchange, water potentials and leaf chlorophyll concentrations

Flooded seedlings showed a transient inhibition in shoot growth and photosynthetic rates which was accompanied by an increase in leaf necrosis during the first month of the flooding treatment (data not shown), but the seedlings recovered in the following months. After six months of flooding, there were no statistically significant differences in root, shoot and total dry weights between flooded and non-flooded plants (Table 1).

Needle chlorophyll concentrations were significantly lower in flooded compared with non-flooded seedlings
Table 1 Seedlings dry weights, needle chlorophyll content (NC), net photosynthesis (NP), transpiration (E), water potential (WP), whole root system hydraulic conductance $\left(\mathrm{K}_{\mathrm{TOT}}\right)$ and hydraulic conductivity $\left(\mathrm{L}_{\mathrm{TOT}}\right)$ in flooded adventitious roots and non-flooded control roots of tamarack seedlings

\begin{tabular}{lcr}
\hline & Non-flooded & Flooded \\
\hline Root DW $(\mathrm{g})$ & $13.8 \pm 0.5$ & $11.8 \pm 1.2$ \\
\hline Shoot DW $(\mathrm{g})$ & $26.5 \pm 1.7$ & $25.7 \pm 3.5$ \\
\hline Total DW $(\mathrm{g})$ & $39.5 \pm 2.3$ & $38.3 \pm 4.7$ \\
\hline Shoot:Root Ratio & $1.9 \pm 0.1$ & $2.3 \pm 0.3$ \\
\hline $\mathrm{NC}\left(\mathrm{mg} \mathrm{g}^{-1} \mathrm{DW}\right)$ & $14.7 \pm 1.0^{\mathrm{a}}$ & $9.4 \pm 0.7^{b}$ \\
\hline $\mathrm{NP}\left(\mu \mathrm{mol} \mathrm{CO} \mathrm{m}^{-2} \mathrm{~s}^{-1}\right)$ & $5.6 \pm 1.2$ & $6.4 \pm 1.5$ \\
\hline $\mathrm{E}\left(\mathrm{mmol} \mathrm{H} \mathrm{O} \mathrm{m}^{-2} \mathrm{~s}^{-1}\right)$ & $0.5 \pm 0.1$ & $0.6 \pm 0.1$ \\
\hline WP $(\mathrm{MPa})$ & $-0.78 \pm 0.04$ & $-0.81 \pm 0.05$ \\
\hline $\mathrm{K}_{\text {TOT }}\left(\mathrm{kg} \mathrm{MPa}^{-1} \mathrm{~s}^{-1} \times 10^{-5}\right)$ & $1.2 \pm 0.2$ & $1.2 \pm 0.4$ \\
\hline $\mathrm{L}_{\text {TOT }}\left(\mathrm{kg} \mathrm{MPa}^{-1} \mathrm{~cm}^{-3} \mathrm{~s}^{-1} \times 10^{-7}\right)$ & $2.0 \pm 0.3$ & $1.6 \pm 0.1$ \\
\hline Differt
\end{tabular}

Different letters within the same row indicate significant differences between flooded and non-flooded plants ( $t$-test, $p=0.05)$. Values are means $\pm S E(n=6$ for $\mathrm{K}_{\text {Tот }}$ and $\mathrm{L}_{\text {Tот }}$ and $\mathrm{n}=7$ for the rest of the measurements).

after six months of treatment (Table 1). However, there were no significant differences in net photosynthesis, transpiration rates and shoot water potentials between the two groups of plants (Table 1).

\section{Root hydraulic properties}

There were no significant differences in the hydraulic conductivity $\left(\mathrm{L}_{\mathrm{TOT}}\right)$ of the whole root systems between non-flooded and flooded seedlings when measured after six months of flooding (Table 1). However, at all measured temperatures ranging from $10{ }^{\circ} \mathrm{C}$ to $30{ }^{\circ} \mathrm{C}$, the hydraulic conductivity $\left(\mathrm{L}_{\mathrm{IND}}\right)$ of individual roots $(20-$ $30 \mathrm{~cm}$ long) was several-fold higher in non-flooded seedlings compared with adventitious roots of flooded plants (Figure 1).

Activation energy $\left(E_{\mathrm{a}}, \mathrm{kcal} \mathrm{mol}^{-1}\right)$ for $\mathrm{L}_{\mathrm{IND}}$ was higher in adventitious roots of flooded plants $(4.95 \pm 0.5)$

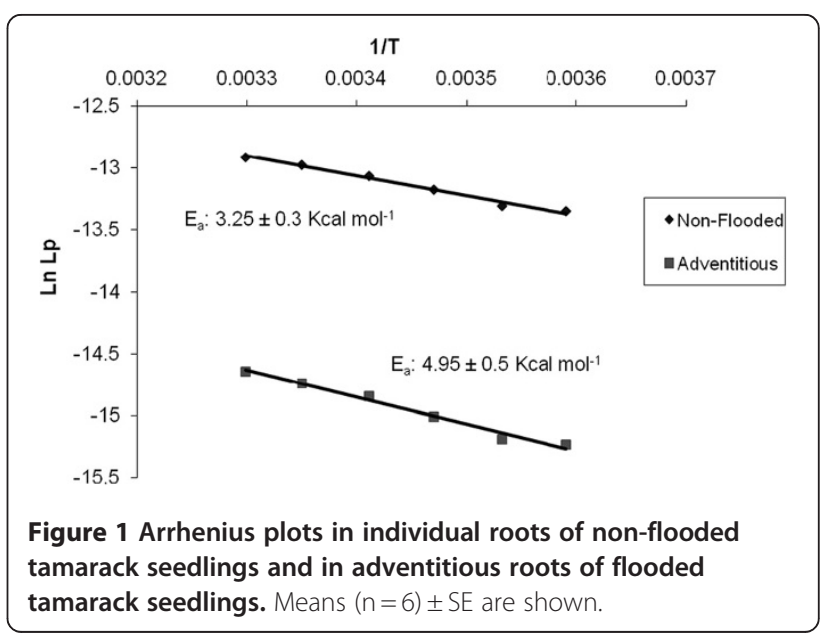


compared with control non-flooded roots $(3.25 \pm 0.3)$ (Figure 1). Similarly, the $\mathrm{PTS}_{3}$ concentration of xylem exudates (\%) was almost two-fold higher in flooded adventitious roots $\left(7.46 \pm 1.1 \times 10^{-3}\right)$ compared with the roots of non-flooded seedlings $\left(4.12 \pm 0.8 \times 10^{-3}\right)$.

\section{Root morphology and structure}

Most of the existing roots disintegrated in plants during the first several months of flooding except for the older woody parts of the roots which comprised about onethird of the whole root system in flooded plants. The adventitious roots were distributed close to the soil surface. Control roots consisted of numerous relatively short, mostly woody and branched roots with relatively short white tips $(2-4 \mathrm{~cm})$ (Figure $2 \mathrm{~A})$. The root system in flooded plants consisted of fewer but longer (up to $30-\mathrm{cm}$ long) adventitious roots (Figure 2B), largely unsuberized and with no secondary tissues present for as far as 10-15 $\mathrm{cm}$ above the root apex.

There were several major structural differences in the zone of the primary tissues between non-flooded roots and adventitious roots. The non-flooded roots contained a well-developed endodermis with suberized cell walls (Figure 3A) and well-developed xylem (Figure 3C) that could be observed close to the root tips. Adventitious roots of flooded plants had poorly-developed endodermis (Figure 3B) and few, small-diameter, tracheids throughout the examined length (up to $5 \mathrm{~cm}$ from the root tip) of the root (Figure 3D).

There was relatively little starch present in the root cells of non-flooded plants (Figure 4A). In contrast, the cortex of flooded adventitious roots was filled with starch grains (Figure 4B).

\section{Inmunolocalization of root aquaporins}

PIP1 and PIP2 antibodies showed similar immunostaining patterns in roots and, therefore, only the PIP1 antiserum is shown. The Western blot analysis showed an immunoreactive band in maize and tamarack root proteins separated by SDS PAGE (Additional file 1). In both species, the band of a molecular weight corresponding to an aquaporin monomer of approximately $30 \mathrm{kD}$ was visible and another, faint, band of approximately $60 \mathrm{kDa}$ corresponding to the aquaporin dimer. The most intense immunofluorescence in the adventitious roots of flooded plants that were incubated with PIP1 and PIP2 antibodies was present in the outer cortical cells and it was less intense in other parts of the root compared with the non-flooded roots (Figure 4D). In non-flooded roots, PIP1 and PIP2 aquaporins were abundant in the root cortex and concentrated especially in its central part away from the epidermis and endodermis (Figure 4C). The stele in adventitious roots and in non-flooded roots incubated with PIP1 and PIP2 also showed relatively intense immunofluorescence.

\section{Discussion}

After a transient inhibition of shoot growth, photosynthesis and the increase in needle necrosis, the recovery and resumption of shoot growth in flooded tamarack coincided with the initiation of adventitious roots. Since the existing younger roots disintegrated over time, there were only old woody roots and new adventitious roots that were present in seedlings at the end of the flooding treatment. Even though needle chlorophyll concentrations were reduced by the flooding treatment, transpiration rates, net photosynthesis, and shoot water potentials were similar in flooded and non-flooded

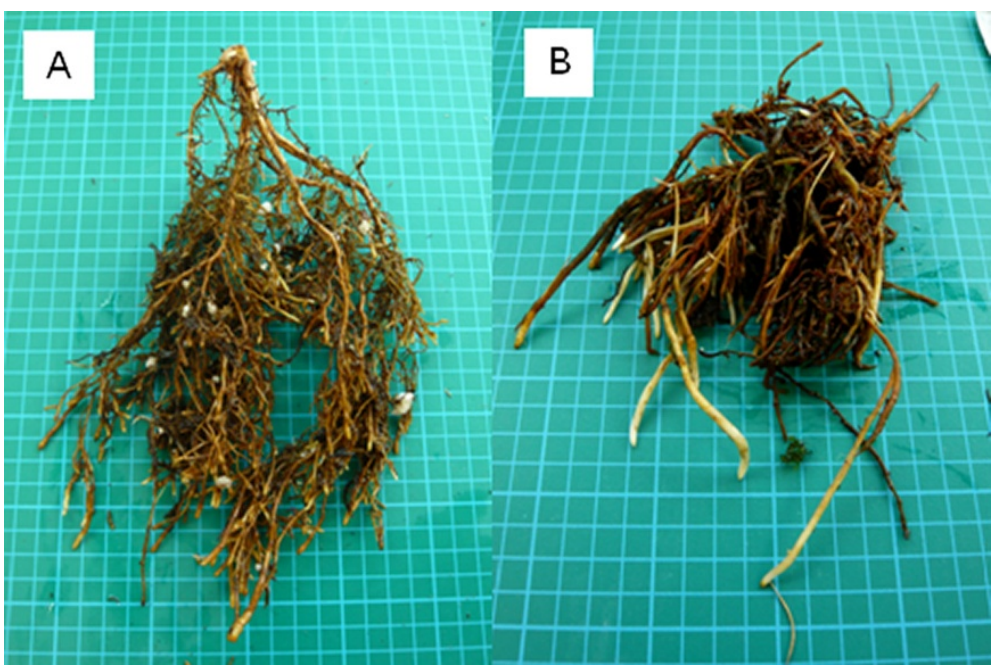

Figure 2 Roots in non-flooded tamarack seedlings (A) and adventitious roots in flooded plants (B) after six months of the flooding treatment. 


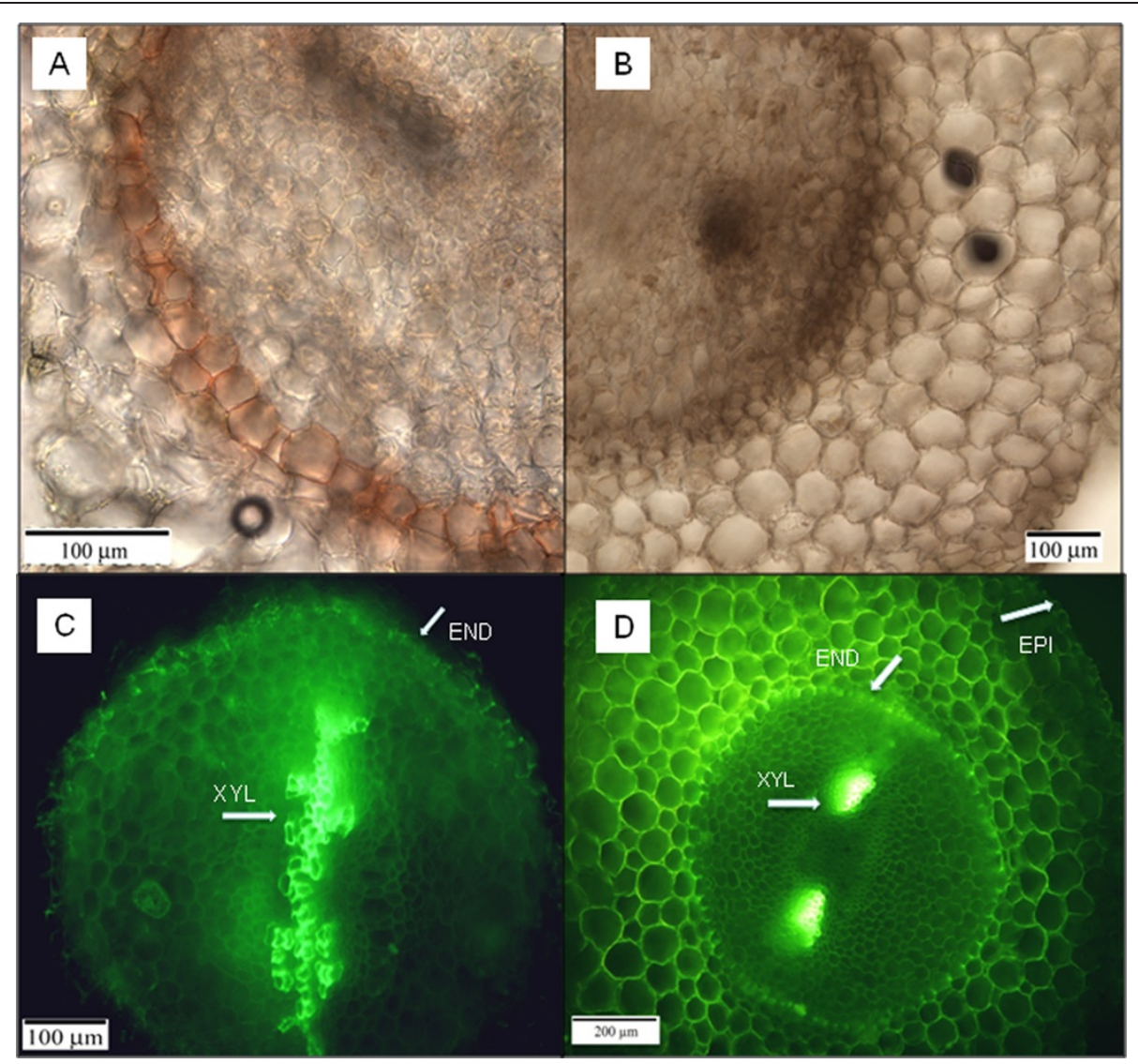

Figure 3 Cross sections of non-adventitious non-flooded roots $(A, C)$ and flooded adventitious roots (B,D) showing reduced size of vascular bundles and poorly-developed endodermis in the adventitious root. The sections were taken at $0-0.2 \mathrm{~cm}$ from the root tip (A,B) and $1 \mathrm{~cm}$ from the root tip $(\mathbf{C}, \mathbf{D})$. The root sections were stained with Sudan IV $(\mathbf{A}, \mathbf{B})$ and berberine $(\mathbf{C}, \mathbf{D})$. The sections for Sudan IV were mounted on slides and examined under the light microscope. The sections for berberine were examined under the fluorescence microscope (Leica DMRXA Upright Microscope) with a green light filter 13 at 450-490 nm excitation and $510 \mathrm{~nm}$ emission. Epidermis (EP), Endodermis (EN) and xylem (XYL) structures are indicated with arrows.

plants. These results suggest that, despite some hypoxiainduced toxicity symptoms, adventitious roots maintained adequate water supply to flooded seedlings. Flooding commonly triggers reductions in leaf chlorophyll concentrations in plants $[4,17]$. The lack of an effect of reduced needle chlorophyll concentrations on net photosynthesis in flooded tamarack suggests that stomatal factors are likely to override photosynthetis responses to flooding under the study conditions.

The initial responses of plants to flooding include an inhibition of gas exchange $[18,19]$. However, transpiration and photosynthesis have been often reported to recover in flooding-tolerant plants $[1,20]$ suggesting that the tolerant plants can restore their water balance over time. The recovery of root hydraulic conductance in flooded tamarack seedlings coincided with the emergence of adventitious roots suggesting that adventitious roots were more flooding-tolerant compared with nonadventitious roots [16]. This recovery is usually related with the production of ethylene within the roots that will induce an increase on root water transport [11] and hence an increase on the phosphorylation of aquaporins. Hypoxia, which is the main consequence of flooding, inhibits root water uptake through its effect on the aquaporin-mediated water transport due to low cytosolic $\mathrm{pH}$ and inhibition of respiration [11,14,21]. Therefore, adaptations of the root system to flooding may be expected to include the structural and functional modifications which decrease the dependence of the root system on the aquaporin-mediated water transport.

In the present study, a large part of the root system in flooded tamarack seedlings consisted of long, nonwoody, adventitious roots with a large unsuberized absorption surface. As part of the adaptations to flooding, the adventitious roots contained greatly reduced vascular bundles when examined as far as $3 \mathrm{~cm}$ from the root apex. Also, their endodermal layer was poorly developed and often not apparent when examined at the same distance from the root apex as the roots of non-flooded plants. The fact that the cortex of adventitious roots 


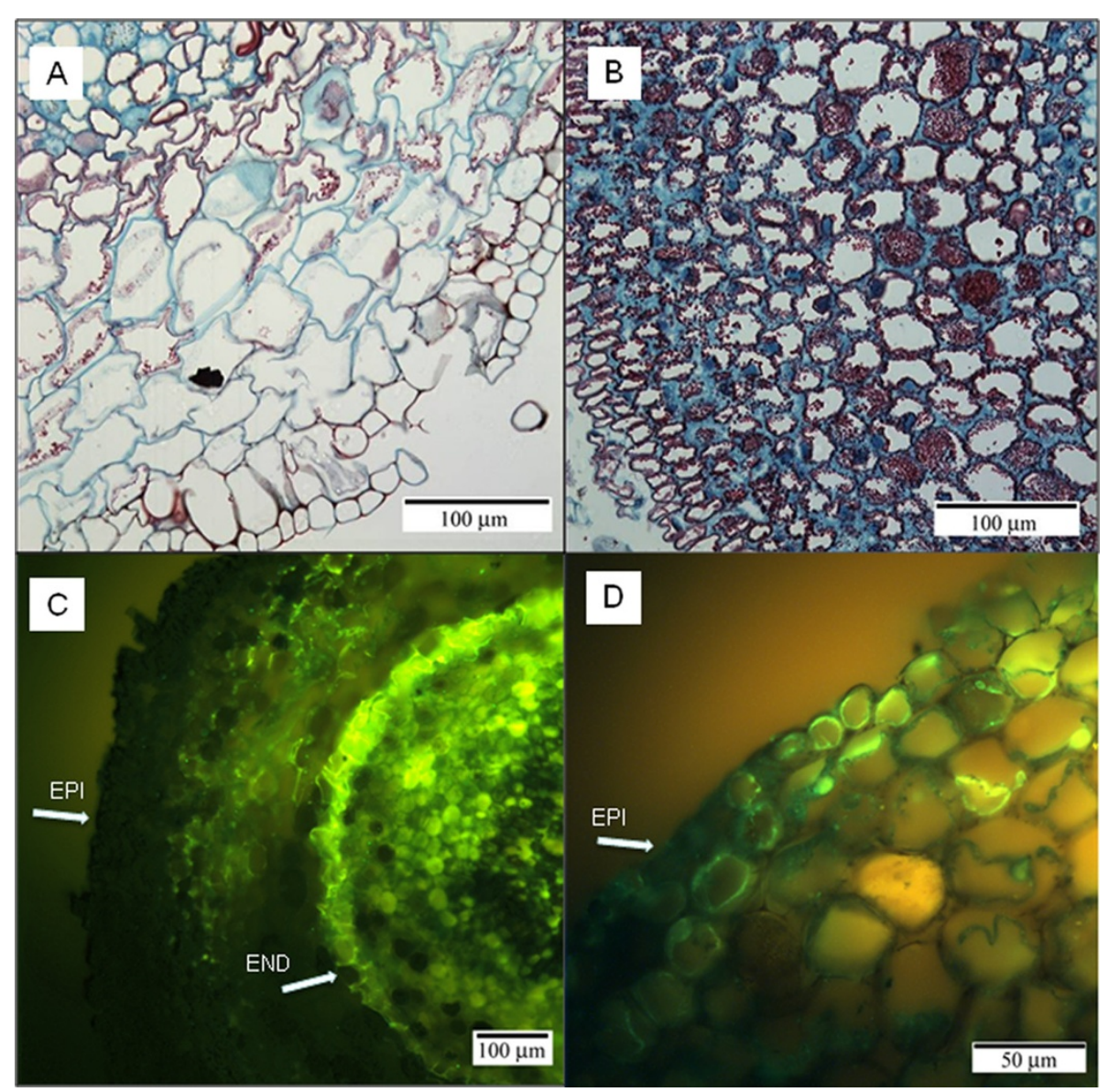

Figure 4 Cross sections of non-adventitious roots from control, non-flooded-plants $(A, C)$ adventitious roots from flooded seedlings $(\mathbf{B}, \mathbf{D})$. The Safranin $\mathrm{O}$ and Fast Green FCF sections show starch accumulation in the cortical cells at $0.5 \mathrm{~cm}$ from the root tip $(\mathbf{A}, \mathbf{B})$. These sections were mounted on slides and examined under the light microscope. Immunolocalication of PIP1aquaporins $(\mathbf{C}, \mathbf{D})$ was carried out with sections taken at $0.5 \mathrm{~cm}$ from the root tip. The sections were examined under the fluorescence microscope (Leica DMRXA Upright Microscope) with a green light filter 13 at 450-490 nm excitation and $510 \mathrm{~nm}$ emission. Epidermis (EP), Endodermis (EN) and xylem (XYL) structures are indicated with arrows.

contained abundant starch grains suggests that they were the sink for carbohydrates. Starch is a primary energy storage compound and its allocation pattern and translocation may be critical for growth and hypoxia tolerance [22]. It has been suggested that plant survival in wetland habitats may depend on root carbohydrate reserves [23] and starch abundance is considered to be among the principal characteristics of flooding-tolerant tree species [24,25]. High accumulation of starch in the rooting regions has been also associated with adventitious root formation [26,27]. It is plausible that large amounts of starch are needed to supply adventitious roots with sufficient energy required to support their growth and basic metabolic functions under hypoxic conditions. However, a possible effect of starch accumulation on matric potential of the root cortex and its consequences for root water relations also deserve further attention.
Both $\mathrm{K}_{\mathrm{TOT}}$ and $\mathrm{L}_{\mathrm{TOT}}$ of the whole root systems were similar in flooded and non-flooded plants (Study 1). When measured in individual roots, $\mathrm{K}_{\mathrm{IND}}$ and $\mathrm{L}_{\mathrm{IND}}$ were several-fold lower in flooded adventitious roots compared with non-flooded control roots (Study 2). Therefore, there were likely water entry points through the parts of the old, partly disintegrated root system. Regardless of the differences in the hydraulic conductance of flooded and non-flooded plants, growth, gas exchange, and shoot water potentials suggest that water transport was not the limiting factor to the flooded plants with established adventitious roots. This was likely facilitated by the greater water absorption area of adventitious roots and structural modifications increasing the apoplastic bypass.

The results of $\mathrm{PTS}_{3}$ and immunostaining with the PIP1 and PIP2 antibodies support the notion of the reduced role of cell-to-cell water transport in 
adventitious flooded roots. The concentration of $\mathrm{PTS}_{3}$ in the xylem sap expressed from the individual flooded adventitious roots was almost two-fold higher compared with control non-flooded roots. $\mathrm{PTS}_{3}$ is a water-soluble fluorescent, non-toxic dye that does not cross cell membranes or adhere to cell walls $[28,29]$. Although the exact concentrations of apoplastic flow calculated from the fluorescent tracer dye concentrations are not precise estimates of the actual apoplastic flow rates, they have been used to estimate relative changes in water flow pathways [10,30-32]. Increases in $\mathrm{PTS}_{3}$ concentrations in the xylem sap have been also correlated with the inhibition of aquaporin-mediated transport in plants exposed to drought $[30,31]$, mercury [31], and metabolic inhibitors $[10,33]$.

Higher activation energy for water flow in flooded adventitious roots $\left(4.95 \mathrm{kcal} \mathrm{mol}^{-1}\right)$ compared with nonflooded control roots $\left(3.25 \mathrm{kcal} \mathrm{mol}^{-1}\right)$ suggests that water transport in flooded adventitious roots is more sensitive to temperature compared with the non-flooded roots. For the transmembrane transport, $\mathrm{E}_{\mathrm{a}}$ increases with increasing restriction of water movement through aquaporins [34,35] and the overexpression of PIP1 and PIP2 aquaporins in Arabidopsis abolishes temperature sensitivity of root cell hydraulic conductivity over the range of 10 to $25{ }^{\circ} \mathrm{C}$ (unpublished results). However, at the whole root level, hydraulic responses to temperature are confounded by the effects of apoplastic pathway $[36,37]$.

The immunolocalization of PIP aquaporins showed that in addition to the overall reduced intensity, immunofluorescence was concentrated in the outer parts of the cortex and epidermis of adventitious flooded roots. This suggests their relatively greater role in the root surface water uptake as demonstrated for PIP2;5 in maize [38]. A more uniform distribution and higher intensity of immunostaining throughout the root cortex of non-adventitious non-flooded roots combined with the presence of larger vascular bundles and well-developed endodermis suggests a greater functional importance of radial water transport in this root zone.

The ability to produce adventitious roots offers an opportunity to tamarack to develop the features that allow trees to survive flooding conditions. It remains to be determined whether the modifications in water transport properties constitute a general flooding tolerance mechanism or are unique to this tree species.

\section{Conclusions}

The study has demonstrated that after six months of flooding, tamarack seedlings had similar shoot water potentials, transpiration rates and net photosynthesis to non-flooded plants. Flooded seedlings produced adventitious roots which accumulated numerous starch grains in the cortex and developed structural modifications which likely contributed to their reduced dependence on the aquaporin-mediated water transport under hypoxic conditions. The reduced dependence of roots on the hypoxia-sensitive aquaporin-mediated water transport is likely among the main mechanisms allowing tamarack seedlings to maintain water balance and gas exchange under flooding conditions.

\section{Methods}

\section{Plant material and growth conditions}

Six-month-old tamarack seedlings were obtained from the Bonnyville Forest Nursery Inc., AB and stored frozen over winter. In spring, the seedlings were transferred into $4.5 \mathrm{~L}$ pots (Nursery Supplies, Tustin, CA) filled with commercial soil mixture (Sunshine LA4 Mix, Sun Grow Horticulture Canada Ltd, Spruce Grove, AB, Canada). The pots were placed in a greenhouse that was maintained at $22 / 18{ }^{\circ} \mathrm{C}$ day/night temperature, 18 -h photoperiod, $65 \pm 10 \%$ relative humidity. Natural light was supplemented with $400-\mathrm{W}$ high pressure sodium lamps giving a minimum photosynthetic photon flux density (PPFD) of $350 \mu \mathrm{mol} \mathrm{m} \mathrm{s}^{-2} \mathrm{~s}^{-1}$ (Lumalux, GTE Sylvania, Drummondville, $\mathrm{PQ}$, Canada). The seedlings were fertilized once a week with the 20:20:20 (N:P:K) commercial fertilizer applied at $0.25 \mathrm{~g} \mathrm{~L}^{-1}$.

After one month, a group of 20 seedlings was subjected to flooding for six months. The flooding treatment was applied by immersing the pots in mineral solution up to about $5 \mathrm{~cm}$ below the top edge. The mineral solution was changed once a week. The initial oxygen concentration of the solution after each weekly change was about $8 \mathrm{mg} \mathrm{L}^{-1}$, and declined over the course of the week to approximately $2-3 \mathrm{mg} \mathrm{L}^{-1}$.

A second group of 20 seedlings served as non-flooded control. The pots with control plants were placed on a greenhouse bench next to the flooded plants and the plants were regularly watered and fertilized as above. The experiment was repeated three times in three different years at the same times during the growing season (Study 1, 2, and 3).

\section{Dry weights, gas exchange and leaf chlorophyll concentrations}

Plant dry weights, gas exchange and leaf chlorophyll concentrations were measured after six months of flooding in Study 1. For dry weight determinations, roots were separated from shoots in six seedlings per treatment $(n=6)$ and their dry weights obtained after drying at $65^{\circ} \mathrm{C}$ for $72 \mathrm{~h}$.

Net photosynthesis (NP) and transpiration (E) rates were measured in the greenhouse between 10:00 and 11:30 using the uppermost branches of six seedlings 
$(n=6)$ per treatment after six months of the flooding treatment. At that time, the upper branches of flooded plants did not shown signs of needle chlorosis or necrosis, which were already apparent in the lower branches. For the gas exchange measurements, an infrared gas analyzer (LCA-4, Analytical Development Company Ltd., Hertfordshire, UK) was used with an auxiliary light source $\left(1000 \mu \mathrm{mol} \mathrm{m}{ }^{-2} \mathrm{~s}^{-1}\right.$ PPFD). Needle surface areas were determined with the Sigma Scan 5.0 software following scanning (Jandel Scientific, San Rafael, CA).

Shoot water potential was measured with a Scholander pressure chamber in the upper lateral branches of the trees. The branches were attached from the stems into the pressure chamber and compressed air was applied. The water potential was determined as the pressure needed for the first drop of water to come out from the branch stem.

Needle chlorophyll concentrations were determined in six seedlings per treatment $(n=6)$ in the same needles as those used for the gas exchange measurements. The needles were freeze-dried and grinded. For chlorophyll determinations, $20 \mathrm{mg}$ DW of tissue was extracted with $8 \mathrm{ml}$ methanol. The methanol extracts were analyzed spectrophotometrically (Ultrospec III, Pharmacia LKB, Uppsala, Sweden) and the MacKinney's equation [39] was used for the calculations of needle chlorophyll concentrations.

\section{Root hydraulic conductance $\left(\mathrm{K}_{\mathrm{TOT}}, \mathrm{K}_{\mathrm{IND}}\right)$, conductivity ( $\mathrm{L}_{\mathrm{TOT}}, \mathrm{L}_{\mathrm{IND}}$ ) and xylem exudate concentrations of 1-hydroxypirene-3,6,8 - trisulfonic acid (PTS 3 )}

Whole root system hydraulic conductance $\left(\mathrm{K}_{\mathrm{TOT}}\right)$ and conductivity $\left(\mathrm{L}_{\mathrm{TOT}}\right)$ were determined after six months of flooding treatment in six flooded and six non-flooded plants $(n=6)$ in Study 1 . The plants were measured at room temperature from 10:00 to 16:00. The shoots of seedlings were excised about $1.5 \mathrm{~cm}$ above the root collar without removing the roots from the soil. The roots were attached to the high pressure flow meter (HPFM, Dynamax Inc., Houston, TX) for $\mathrm{K}_{\mathrm{TOT}}$ measurements. Each root system was gradually pressurized to $0.5 \mathrm{MPa}$ [40]. After the measurements, root volumes were calculated using the volume displacement method [33] and $\mathrm{L}_{\mathrm{TO}}$ was calculated.

For Study 2, root hydraulic conductance measurements were carried out with a HPFM on sets of individual roots $\left(\mathrm{K}_{\mathrm{IND}}\right)$ cut at the stem level (Figure 2) of six non-flooded plants and on six adventitious roots from flooded seedlings $(n=6)$. For the measurements, the roots were placed in a water bath at $10{ }^{\circ} \mathrm{C}$ and their $K_{\text {IND }}$ was determined at increasing temperatures from $10,15,20,25$, to $30{ }^{\circ} \mathrm{C}$. The roots were held for $10 \mathrm{~min}-$ utes after each temperature change before the measurement. Root hydraulic conductivity $\left(\mathrm{L}_{\mathrm{IND}}\right)$ was calculated based on the root volume calculated by the volume displacement method as explained above.
The activation energy $\left(E_{a}, \mathrm{kcal} \mathrm{mol}^{-1}\right)$ for root water transport was calculated from the Arrhenius plots of the natural logarithm of $L_{\text {IND }}$ values against the inverse of absolute temperatures [41].

The apoplastic tracer dye 1-hydroxypirene-3,6,8 - trisulfonic acid $\left(\mathrm{PTS}_{3}\right)$ was used to examine relative changes in the apoplastic to cell-to-cell water flow ratio in the roots. $\mathrm{PTS}_{3}$ is a fluorescent dye that is not transported across the cell membranes and which have been often used to estimate changes in ratio of apoplastic measurements of cell-to-cell water transport in roots. For the measurements, we used the same sets of roots as in the measurements of $\mathrm{L}_{\mathrm{IND}}$. The roots were placed in a Scholander pressure chamber in an aqueous solution of $0.02 \%$ (w:v) $\mathrm{PTS}_{3}$, and pressurized at $0.3 \mathrm{MPa}$ for 10 min [31]. The exudates were collected and $\mathrm{PTS}_{3}$ concentrations were determined using a Sequoia-Turner 450 fluorometer (Apple Scientific, Chesterland, $\mathrm{OH}$, USA) with $405 \mathrm{~nm}$ excitation and $515 \mathrm{~nm}$ emission spectra [28].

\section{Root anatomy and root starch content}

Root tips of eight control-non flooded seedlings and eight distal root segments of adventitious and nonadventitious flooded seedlings were randomly selected after 6 months of flooding treatment (between 0.5- and $1-\mathrm{cm}$ long in Study 1 and up to 5-cm long in Study 3). In Study 1, the root segments were fixed with FAA (70\% ethanol, glacial acetic acid and formalin) overnight followed by $4 \%$ paraformaldehyde and $0.5 \%$ glutaraldehyde for $6 \mathrm{~h}$. After fixation, the root segments were dehydrated in an ethanol series, placed in toluene and embedded in paraffin. Serial cross sections $(6-8-\mu \mathrm{m}$ thick) of paraffin-embedded roots were prepared with a microtome. The paraffin sections were cleared with toluene and $95 \%$ ethanol and stained with $0.1 \%$ Safranin O (in 95\% ethanol (w:v) for $1 \mathrm{~h}$ follow by $0.1 \%$ Fast Green FCF in 95\% ethanol (w:v) for $1 \mathrm{~min}$. The sections were mounted on slides and examined under the light microscope.

The development of xylem and endodermal tissues were examined in Study 3. Root segments were obtained at different distances from the fresh root tips $(0,0.5,1$, $1.5,2$, and $3 \mathrm{~cm}$ ). Fresh, free-hand sections were prepared with a razor blade and stained with Sudan IV or Berberine [42]. The sections were examined with the light and fluorescent microscope (Leica DMRXA Upright Microscope) using a green light filter I3 at 450$490 \mathrm{~nm}$ excitation and $510 \mathrm{~nm}$ emission.

Starch content and distribution was examined in fresh, free-hand sections taken up to $1 \mathrm{~cm}$ from the root tip of non-flooded roots and adventitious roots from flooded plants. The sections were stained with IKI and viewed under the light microscope. 


\section{Inmunolocalization of root aquaporins}

For in situ immunolocalization of aquaporins, fresh free-hand sections were prepared with a razor blade from the roots of six non-flooded and flooded seedlings. The sections were taken from 0.5 to $1 \mathrm{~cm}$ from the root tip. They were incubated with the antibodies raised against PIP1 and PIP2 aquaporins [38]. The anti-PIP1 antibody (R-4445) was raised against an amino peptide from ZmPIP1;5 and recognizes all maize PIP1s except PIP1;6 [38]. The anti-PIP2 antibody (R-2493) was raised against an amino peptide from ZmPIP2;4 and was shown to recognize all maize PIP2s (Dr. F. Chaumont personal communication). Following incubation in blocking solution (5\% BSA in phosphate buffer solution) and in the anti-PIP1, PIP2, and preimmune antibodies (1:1000 dilution by volume), the sections were incubated in the fluorescein-coupled goat anti-rabbit IgG antibody (Sigma-Aldrich Canada Ltd., ON, Canada). The slides were examined under the fluorescence microscope (Leica DMRXA Upright Microscope) with a green light filter I3 at 450-490 nm excitation and $510 \mathrm{~nm}$ emission.

To determine the specificity of polyclonal antibodies, sodium dodecyl sulfate-polyacrylamide gel electrophoresis (12\% acrylamide resolving gel) was performed with proteins $(30 \mu \mathrm{g})$ extracted from the roots of a two-year old tamarack (Larix laricina) and two-week old greenhouse-grown maize (Zea mays). Following electrophoresis, gels were electroblotted to PVDF membrane, blocked overnight in Tris-buffered saline containing 5\% $(\mathrm{w} / \mathrm{v})$ bovine serum albumin and probed with primary polyclonal antibodies (1:500) raised against Zea mays PIP1 and PIP2 aquaporins that were used for the immunolocalization [38]. Secondary antibody $(1: 10,000)$ raised in goat against rabbit IgG and conjugated to alkaline phosphatase (Sigma-Aldrich) was used to detect immunoreactive bands.

\section{Statistical analysis}

The data were analyzed using SAS (version 9.1, SAS Institute Inc.; Cary, NC, USA). T-test was used to determine significant differences between treatment means of water relation and physiological parameters at $\alpha=0.05$. Analysis of variance (ANOVA) with the Mixed Procedure of SAS was used to determine differences in $\mathrm{L}_{\mathrm{IND}}$ of individual roots at different temperatures at $\alpha=0.05$.

\section{Additional file}

Additional file 1: SDS Page of the proteins extracted from maize (1) and tamarack (2) roots and stained with Coomassie blue (left).

Immunoblot of maize (1) and tamarack (2) proteins probed with ZmPIP1 antibody R-4445 (right).
Authors' contributions

MC-P carried out and designed the experiments, performed statistical analyses of the data and drafted the manuscript. JS was in charge of growing plants and flooding treatments, assisted in measurements, and prepared tissue sections for microscopy. JJZ was responsible for designing the study, interpreting results co-drafting and editing the manuscript. All authors have read and approved the manuscript.

\section{Acknowledgements}

We would like to thank the Natural Sciences and Engineering Council of Canada for research funding, Dr. Jang for her help with the Western blot analysis, Dr. François Chaumont from the Catholique University of Louvain for providing the PIP1 and 2 antibodies, and the Advanced Microscopy Facility Biological Sciences, University of Alberta for help with microscopy and for the use of facilities.

Received: 6 December 2011 Accepted: 23 May 2012

Published: 27 June 2012

\section{References}

1. Herrera A, Tezara W, Marin O, Rengifo E: Stomatal and non-stomatal limitations of photosynthesis in trees of a tropical seasonally flooded forest. Physiol Plantarum 2008, 134:41-48.

2. Herschbach C, Mult S, Kreuzwieser J, Kopriva S: Influence of anoxia on whole plant sulphur nutrition of flooding-tolerant poplar (Populus tremula x P.alba). Plant Cell Environ 2005, 28:167-175.

3. Pezeshki SR: Wetland plant responses to soil flooding. Environ Exp Bot 2001, 46:299-312.

4. Armstrong W, Brändle R, Jackson MB: Mechanisms of flood tolerance in plants. Act Bot Neerl 1994, 43:307-358.

5. Li S, Pezeshki SR, Shields FD Jr: Partial flooding enhances aeration in adventitious roots of black willow (Salix nigra) cuttings. J Plant Physiol 2006, 163:619-628.

6. Van Cleve K, Oliver LK, Chlentner LA, Viereck LA, Dyrness CT: Productivity and nutrient cycling in taiga forest ecosystems. Can J Forest Res 1983, 13:747-766.

7. Denver GB, Riley CG: Dieback and mortality of tamarack caused by high water. Forest Chron 1964, 40:334-338.

8. Lieffers VJ, Rothwell RL: Effects of depth and water table and substrate temperature on root and top growth of Picea mariana and Larix laricina. Can J Forest Res 1986, 16:1201-1206.

9. Mielke M, Schaffer B: Leaf gas exchange, chlorophyll fluorescence and pigment indexed of Eugenia uniflora L. in response to changes in light intensity and soil flooding. Tree Physiol 2010, 30:45-55.

10. Kamaluddin M, Zwiazek JJ: Metabolic inhibition of root water flow in red-osier dogwood (Cornus stolonifera) seedlings. J Exp Bot 2001, 52:739-745.

11. Kamaluddin M, Zwiazek JJ: Ethylene enhances water transport in hypoxic aspen. Plant Physiol 2002, 128:962-969.

12. Bramley H, Turner NC, Turner DW, Tyermann SD: The contrasting influence of short-term hypoxia on the hydraulic properties of cells and roots of wheat and lupin. Funct Plant Biol 2010, 37:183-193.

13. Zhang $\mathrm{WH}$, Tyerman SD: Effect of low $\mathrm{O}_{2}$ concentrations and azide on hydraulic conductivity and osmotic volume of the cortical cells of wheat roots. Aus J Plant Physiol 1991, 18:603-613.

14. Tournaire-Roux C, Sutka M, Javot H, Gout E, Gerbeau P, Luu DT, Bligny R, Maurel $\mathrm{C}$ : Cytosolic $\mathrm{pH}$ regulates root water transport during anoxic stress through gating of aquaporins. Nature 2003, 425:393-397.

15. Islam MA, Macdonald SE, Zwiazek JJ: Responses of black spruce (Picea mariana) and tamarack (Larix laricina) to flooding and ethylene treatments. Tree Physiol 2003, 23:545-552.

16. Islam MA, Macdonald SE: Ecophysiological adaptations of black spruce (Picea mariana) and tamarack (Larix laricina) seedlings to flooding. Trees-Struct Funct 2004, 18:35-42.

17. Grichko VP, Glick BR: Flooding tolerance of transgenic tomato plants expressing the bacterial enzyme ACC deaminase controlled by the $35 \mathrm{~S}$, rolD or PRB-1b promoter. Plant Physiol Biochem 2001, 39:19-25.

18. Bradford $\mathrm{KJ}$ : Effects of soil flooding on leaf gas exchange of tomato plants. Plant Physiol 1983, 73:475-479. 
19. Copolovici L, Niinemets U: Flooding induced emissions of volatile signaling compounds in three tree species with differing waterlogging tolerance. Plant Cell Environ 2010, 33:1582-1594.

20. Reece CF, Riha SJ: Role of root systems of eastern larch and white spruce in response to flooding. Plan Cell Environ 1991, 14:229-234.

21. Birner TP, Steudle E: Effects of anaerobic conditions on water and solute relations, and on active transport in roots of maize (Zea mays L.). Planto 1993, 190:474-483.

22. Huang $B$, Johnson JW: Root respiration and carbohydrate status of two wheat genotyupes in response to hypoxia. Ann Bot 1995, 75:427-432.

23. Barclay AM, Crawford RMM: The effect of anaerobiosis on carbohydrate levels in storage tissues of wetland plants. Ann Bot 1983, 51:255-259.

24. Gravatt DA, Kirby CJ: Patterns of photosynthesis and starch allocation in seedlings of four bottomland hardwood tree species subjected to flooding. Tree Physiol 1998, 18:411-417.

25. Gérard B, Alaoui-Sossé B, Badot BM: Flooding effects on starch partitioning during early growth of two oak species. Trees Struct Funct 2009, 23:373-380.

26. Li M, Leung DWM: Starch accumulation is associated with adventitious root formation in hypocotyls cuttings of Pinus radiata. J Plant Growth Regul 2000, 19:423-428.

27. Ahkami AH, Lischewski S, Haensch KT, Porfirova S, Hormann J, Rolletscheck H, Melzer M, Franken P, Hause B, Druege U, Hajirezaei MR: Molecular physiology of adventitious root formation in Petunia hybrida cuttings: involvement of wound response and primary metabolism. New Phytol 2009, 181:613-625.

28. Skinner RH, Radin JW: The effect of phosphorus nutrition on water flow through the apoplastic by-pass of cotton roots. J Exp Bot 1994, 45:423-428.

29. Vesk PA, Ashford AE, Markovina A-L, Allaway WG: Apoplasmic barriers and their significance in the exodermis and sheath of Eucalyptus pilularisPisolithus tinctorius ectomycorrhizas. New Phytol 2000, 145:333-346.

30. Siemens JA, Zwiazek JJ: Effects of water deficit stress and recovery on the root water relations of trembling aspen (Populus tremuloides) seedlings. Plant Sci 2003, 165:113-120.

31. Siemens JA, Zwiazek JJ: Changes in root water flow properties of solution culture grown trembling aspen (Populus tremuloides) seedlings under different intensities of water-deficit stress. Physiol Plantarum 2004, 121:44-49.

32. Faiyue B, Al-Azzawi MJ, Flowers TJ: The role of lateral roots in bypass flow in rice (Oryza sativa L.). Plant Cell Environ 2010, 33:702-716.

33. Voicu MC, Zwiazek JJ: Cycloxeximide inhibits root water flow and stomatal conductance in aspen (Populus tremuloides) seedlings. Plant Cell Environ 2004, 27:199-208.

34. Maurel C: Aquaporins and water permeability of plant membranes. Ann Rev Plant Physiol Plant Mol Biol 1997, 48:399-429.

35. Shütz K, Tyerman SD: Water channels in Chiara coralline. J Exp Bot 1997, 48:1511-1518.

36. Wan X, Landhäusser SM, Zwiazek JJ, Lieffers VJ: Root water flow and growth of aspen (Populus tremuloides) at low root temperatures. Tree Physiol 1999, 19:879-884.

37. Kamaluddin $\mathrm{M}$, Zwiazek JJ: Effects of root medium $\mathrm{pH}$ on water transport in paper birch (Betula papyrifera) seedlings in relation to root temperature and abscisic acid treatments. Tree Physiol 2004, 24:1173-1180

38. Hachez C, Moshelion M, Zelazny E, Cavez D, Chaumont F: Localization and quantification of plasma membrane aquaporin expression in maize primary root: a clue to understanding their role as cellular plumbers. Plant Mol Biol 2006, 62:305-323.

39. Šesták Z, Čatský J, Jarvis PG: Plant photosynthetic production. Manual of methods. The Hague: Dr W. Junk N-V Publishers; 1971.

40. Tyree MT, Patiño S, Bennink J, Alexander J: Dynamic measurements of root hydraulic conductance using a high-pressure flowmeter in the laboratory and field. J Exp Bot 1995, 46:83-94.

41. Nobel PS: Physiochemical and environmental plant physiology. London: Academic; 1991

42. Peterson RL, Peterson CA, Melville L: Teaching plant anatomy through creative laboratory exercises. Ontario: NCR Press; 2009.

\section{doi:10.1186/1471-2229-12-99}

Cite this article as: Calvo-Polanco et al: Role of adventitious roots in water relations of tamarack (Larix laricina) seedlings exposed to flooding. BMC Plant Biology 2012 12:99.

\section{Submit your next manuscript to BioMed Central and take full advantage of:}

- Convenient online submission

- Thorough peer review

- No space constraints or color figure charges

- Immediate publication on acceptance

- Inclusion in PubMed, CAS, Scopus and Google Scholar

- Research which is freely available for redistribution 